УДК 616.314.17-008.1-037.17-022.6

DOI: $10.26435 /$ UC.V0I3(36).526

\author{
В.В. Глинкин, В.А. Клемин, Р.Б. Кондратюк
}

ГОО ВПО «Донецкий национальный медицинский университет имени М. Горького», Донецк

\title{
НАЛИЧИЕ И ЛОКАЛИЗАЦИЯ МИКРОФЛОРЫ В ЗУБАХ С ДЕСТРУКТИВНЫМИ ФОРМАМИ ПЕРИОДОНТИТОВ
}

Периодонтит до сих пор остается распространенным осложнением кариозного процесса. Чаще всего в стоматологической практике встречаются инфекционные периодонтиты. Апикальный периодонтит считается заболеванием бактериальной этиологии [1]. В корневых каналах встречаются анаэробные бактерии более чем в 70\% случаев [2]. Было обнаружено, что по мере утяжеления течения заболевания увеличивался диапазон микробного пейзажа и частота высевания условно патогенной и патогенной микрофлоры [3]. Но только при наличии генетически обусловленных факторов адгезии у микрофлоры возможна колонизация данным видом микрофлоры биологической ниши организма. Факторы адгезии, протекции, колонизации являются основой патогенного действия, но не тождественны ему. Для развития апикального деструктивного периодонтита необходимо не только, чтобы превалировал определенный вид микрофлоры, но и количество микрофлоры должно достигать некоторого определенного порогового уровня. Какое это пороговое значение, чтобы развился апикальный периодонтит у определенного человека неизвестно. [4, 5]. Помимо этого, микроорганизм должен обладать фактором патогенности.

Микрофлора является прекрасным антигеном, т.к. это генетически чужеродная молекула, против которой в организме формируется реакция специфического противодействия. Даже нормальная микрофлора в процессе своей жизнедеятельности способствует изменению окислительно-восстановительного потенциала, создавая условия для развития анаэробов, вызывающих ряд патологических изменений в соединительной ткани, вызывая расстройства микроциркуляции [6], является фактором неспецифической резистентности местного иммунитета.

Микрофлора является пусковым механизмом развития заболевания, а уже дальше начинаются изменения на внутриклеточном уровне, т.е. вступают в силу патогенетические факторы [7]. Микрофлора корневых каналов, как чу- жеродная молекула, формирующая в организме реакцию специфического иммунитета, определяет гистологические и иммуногистохимические особенности воспалительных инфильтратов смешанно-клеточного строения $[8,9]$.

До сих пор происхождение и локализация микрофлоры в закрытых очагах является нерешенным вопросом [10].

Микроорганизмы и их токсичные продукты метаболизма, приводящие к периапикальному воспалению, определили цель эндодонтического лечения, которая заключается в устранении патогенных бактерий и предотвращении повторного инфицирования. Поэтому перед эндодонтистом стоит задача как наиболее оптимально добиться поставленной цели. Для этого необходимо четко представлять с чем приходится бороться, где этот «противник» находится и какими средствами располагает.

Не смотря на то, что видовой состав и патогенные свойства микрофлоры давно и тщательно изучаются, наличию и локализации микрофлоры в зубах с периодонтальной патологией, особенно в стадии обострения уделено мало внимания [11].

\section{ЦЕЛЬ ИССЛЕДОВАНИЯ}

Изучить и проанализировать наличие и локализацию микрофлоры в зубах с деструктивными формами периодонтитов.

\section{МАТЕРИАЛ И МЕТОДЫ}

Для изучения патоморфологических изменений, происходящих в тканях зуба и периодонта в момент обострения хронического процесса нами был изучен материал полученный при удалении 46 зубов у 42 пациентов (22 мужчины и 20 женщин) в возрасте от 23 до 79 лет с хронического апикальным периодонтитом в стадии обострения. Все зубы ранее не были лечены. Для

(c) В.В. Глинкин, В.А. Клемин, Р.Б. Кондратюк, 2020 (c) Университетская Клиника, 2020 
морфологического исследования использовали биоптаты гранулем зубов с гранулематозным периодонтитом в стадии обострения. Материал был получен при удалении 13 зубов с гранулемами. Так же были изучены 6 зубов с диагнозом хронический периодонтит (3 мужчины и 3 женщины) в возрасте от 30 до 82 лет.

Забор материала осуществлялся в момент стоматологической манипуляции удаления зубов после проведения инъекционного обезболивания 2\% раствором лидокаина или Septanest, содержащий в 1 мл препарата 40 мг артикаина и 0,01 мг адреналина с информационного согласия пациента. Право пациентов на участие в исследовании на основании добро- вольного согласия гарантировано письменным согласием обследуемых пациентов после получения ими информации о характере исследования и отсутствии возможных осложнений.

Подготовку материала осуществляли по общепринятым методикам [12] и изучали с помощью светового микроскопа Olympus BX-40. Maтериал фиксировали в $10 \%$ растворе формалина. Время фиксации 24 часа при комнатной температуре. После этого приступали к декальцинации 10\% азотной кислотой на протяжении 4-6 суток, меняя декальцинирующую жидкость каждые сутки. После окончания декальцинации объекты тщательно промывали в проточной воде и проводили обезвоживание при комнат-

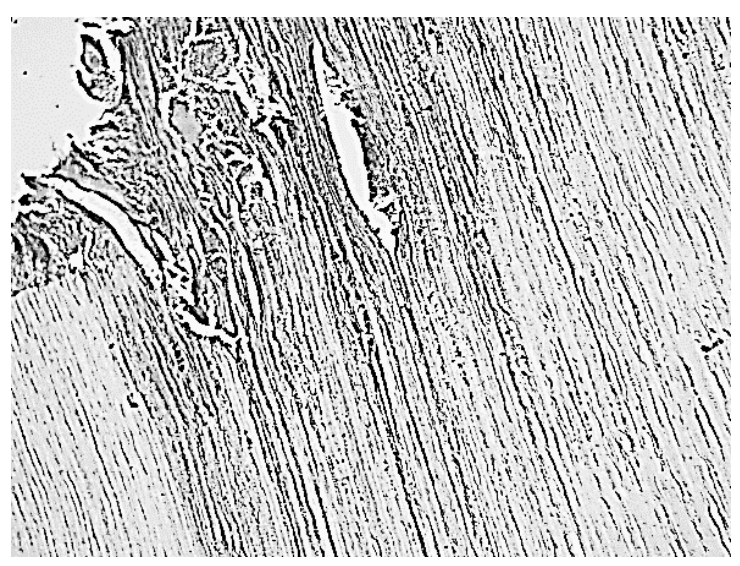

a.

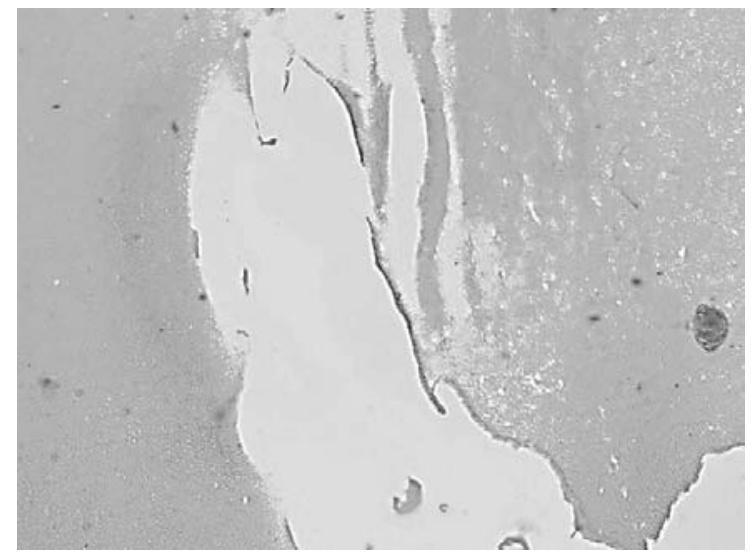

B.

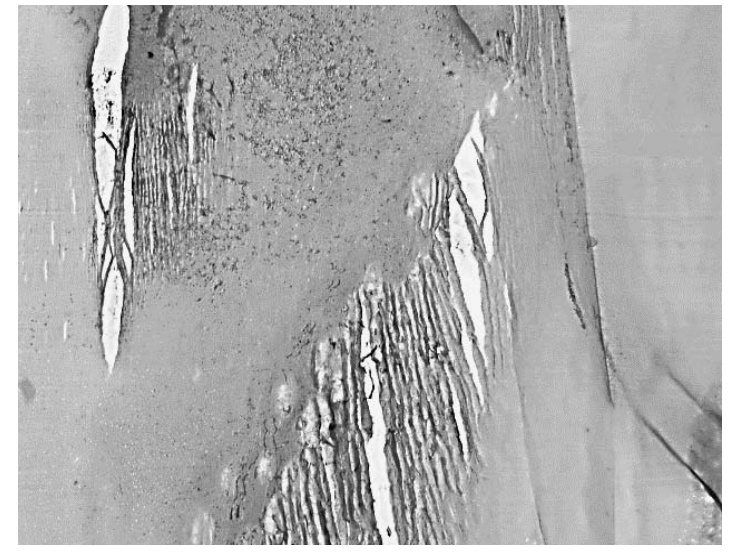

б.

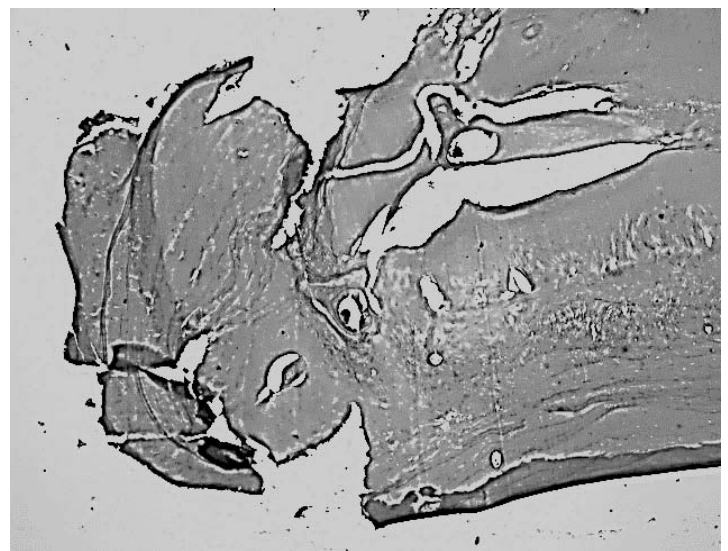

$\Gamma$.

Рис. 1. Микропрепараты. а. Участок кариозной полости 27 зуба с мелкими кавернами вокруг. Дентинные канальцы заполнены микрофлорой. Окраска гематоксилином и эозином, $\times 200$.

б. Дентинные канальцы 36 зуба заполненные микрофлорой, чередующиеся с некрозом дентина в средней трети корня. Окраска гематоксилином и эозином, ×100;

в. Участок апикального отверстия 17 зуба с явлением обширной резорбции цемента. Дентинные канальцы в области верхушки корня без признаков микрофлоры. Окраска гематоксилином и эозином, $\times 100$;

г. Обширная по площади и глубине резорбция цемента и дентина в области апикального отверстия 45 зуба. Очаги микрофлоры в дентинных канальцах в апикальной области не значительные по объему. Окраска гематоксилином и эозином, $\times 40$. 
ной температуре в спиртах возрастающей концентрации: 1 проведение - 70\% спирт, 2-е - 80\%, 3-5-е - 96\%. На каждое проведение уходили сутки. Обезвоживание в спиртах имеет целью подготовить ткани к пропитыванию парафином. Это обезвоживание носило предварительный характер и, обезвоженные спиртом биоптаты, подвергали дополнительной обработке, помещая в среду, которая способна смешиваться со спиртом и является хорошим растворителем парафина. Для этих целей использовалась промежуточная среда хлороформ. Исследуемый материал трижды помещали в хлороформ по 45 минут. Хлороформ меняли во избежание излишнего насыщения его спиртом и жирами. Это делали с целью более легкого пропитывания объекта исследования парафином. После этого приготовляли смесь из хлороформа и предварительно растопленного парафина (50/50) в термостате при температуре $37^{\circ} \mathrm{C}$ в течение 30-40 мин. Заливку объекта в формочку с паропластом проводили в термостате при температуре $62^{\circ} \mathrm{C} 2$ раза по 45 мин. После заливки объект остывал в воде. Из застывшего парафина вырезали блоки соответственно заключенным объектам. Срезы из полученного материала нарезали на микротоме МПС-2 толщиной 4-5 мкм и натягивали на стекла. Сушили 12 часов при температуре $37^{\circ} \mathrm{C}$. Высушенным срезам проводили депарафинизацию, затем окрашивали гематоксилином и эозином. После этого заключали срезы.

\section{РЕЗУЛЬТАТЫ И ОБСУЖДЕНИЕ}

Микрофлора была обнаружена в биоптатах 23 зубов, что составило 50\% обследуемых зу- бов. В 19 случаях, когда микрофлора была обнаружена в кариозной полости зуба, она находилась на границе с пульповой камерой, часто на большом протяжении и проникала в дентинные канальцы на незначительную глубину. При этом наблюдались трещины, идущие поперек дентинных канальцев. Микрокаверны были обнаружены в 12 (26\%) из 46 зубов, присутствовали как самостоятельно, так и сочетались с трещинами, были либо свободные, либо заполненные микрофлорой и кровью. Во всех случаях, когда микрофлору обнаруживали в корневой части зуба, она располагалась локально, занимала небольшие поверхности на незначительной глубине. Микрофлора была обнаружена как со стороны пульпы, так и со стороны периодонта. В 4 случаях микрофлора проникала в дентинные канальцы со стороны периодонта через зубодесневой карман являющийся патологическим и при этом со стороны пульпы она не наблюдалась: в 3 - в пришеечной трети корня и в 1 - в средней трети. При этом она располагалась на ограниченных участках (чаще один участок). В 12 (26\%) случаях в зубах, где в дентинных канальцах присутствовала микрофлора, клеточная инфильтрация в них отсутствовала. А в тех случаях, когда клетки присутствовали, то находились в зубе в области средней или верхней трети корня, либо в периодонте.

В 23 случаях начиная с пришеечной области и вдоль всей длины корня, вплоть до апикального отверстия дентинные трубочки оставались чистыми от микрофлоры (рис. 1.).

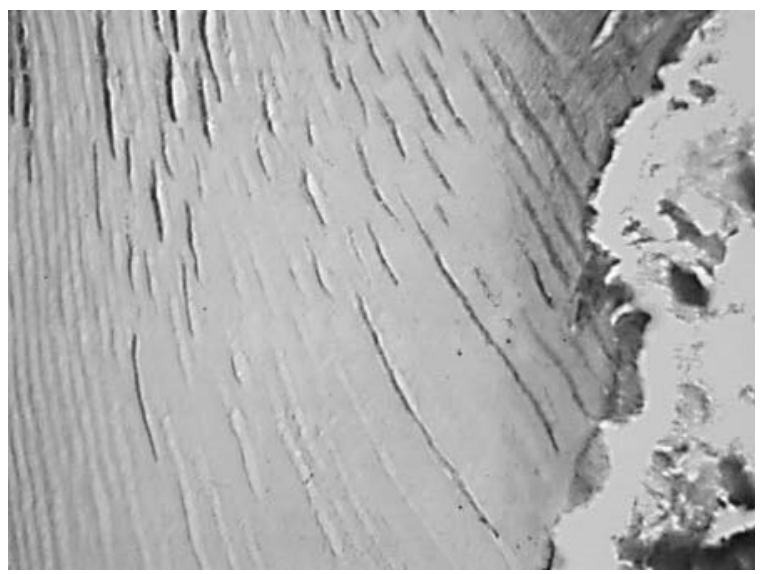

б.

Рис. 2. Микропрепараты. а. Дентинные канальцы 42 зуба, заполненные микрофлорой возле кариозной полости. Окраска гематоксилином и эозином, $\times 200$;

б. Резорбция цемента и дентина, отсутствие периодонта в области верхушки корня. Наличие микрофлоры в некоторых дентинных канальцах на всем протяжении дентина вплоть до цемента. Окраска гематоксилином и эозином, $\times 400$ 
Мы не можем достоверно утверждать, что микрофлора не присутствовала в других случаях, т.к. для исследования предварительно декальцинированных биоптатов использовали окраску только гематоксилином и эозином, а как доподлинно известно некоторые виды микрофлоры можно обнаружить только при выделении из прижизненных биопсийных образцов и при использовании других методов окраски.

При исследовании 6 зубов с хроническими формами апикальных периодонтитов во всех случаях было обнаружено очаговое расположение микрофлоры в кариозных полостях и в области пришеечной и средней трети корней. В коронковой части 2 зубов в кариозных полостях обнаружены микрокаверны, заполненные микрофлорой. В 3 (50\%) случаях она доходила до апикальной трети корня. В этих случаях присоединялась пародонтальная патология. В 2 из 3 случаев наблюдали резорбцию цемента и дентина в апикальной области. Во всех исследуемых зубах микрофлора занимала огромные площади и проникала практически на всю толщину дентина, вплоть до наружной поверхности корня (рис. 2.).

Ни в одном случае микрофлора не была обнаружена за пределами твердых тканей зуба, даже в тех случаях, когда наблюдали резорбцию и отсутствие периодонта. Наибольшее количество микрофлоры находилось в непосредственной близости к пульповой камере. По мере приближения к наружной поверхности корня зуба ее количество уменьшалось.

Необходимо отметить, что в исследуемых гранулемах ни в одном случае микрофлора не была обнаружена.

\section{В Ы В ОД Ы}

При обострении хронического периодонтита микрофлора располагалась локально на незначительной глубине, рядом с пульповой камерой, преимущественно в пришеечной и средней трети корня. Не обнаружение микрофлоры в половине обследованных зубов говорит о том, что для поддержания воспаления в тканях зуба и периодонта ее присутствие на протяжении всего течения воспалительного процесса не обязательно, но в тоже время мы не можем с абсолютной уверенностью утверждать о ее полном отсутствии ввиду ограниченности метода ее исследования. С наружной поверхности корня микрофлора присутствовала только в случаях сочетанной пародонтальной патологии. Во всех зубах с хроническим течением периапикальной патологии микрофлора хоть и была локализована, но проникала на большую глубину, вплоть до цемента корня, и захватывала обширные площади. В половине случаев она доходила до верхушки корня, но не выходила за пределы цемента. Учитывая огромные площади обсемененных микрофлорой дентинных канальцев в зубах с хроническими формами периодонтитов логично предложить клиницистам не переводить зубы находящиеся в стадии обострения в хроническую форму течения заболевания, предотвратив тем самым их реинфицирование, а после тщательной хемомеханической обработки герметично закрывать их уже в первое посещение.

\section{В.В. Глинкин, В.А. Клемин, Р.Б. Кондратюк}

ГОО ВПО «Донецкий национальный медицинский университет имени М. Горького», Донецк

НАЛИЧИЕ И ЛОКАЛИЗАЦИЯ МИКРОФЛОРЫ В ЗУБАХ
С ДЕСТРУКТИВНЫМИ ФОРМАМИ ПЕРИОДОНТИТОВ

Видовой состав и патогенные свойства микрофлоры зубов с периодонтальной патологией изучаются давно, но наличию и локализации микрофлоры в зубах с хроническими периодонтитами том числе в стадии обострения уделено мало внимания. Нашей целью было изучение наличия и локализации микрофлоры в зубах с деструктивными формами периодон- титов. Было выявлено, что при хронических формах периодонтитов и в стадии обострения локализация микрофлоры одинакова, но наличие и распространенность ее в твердых тканях зуба отличается.

Ключевые слова: периодонтит, микрофлора, наличие, локализация. 


\section{V.V. Glinkin, V.A. Klyomin, R.B. Kondratyuk}

\section{SEI HPE «M. Gorky Donetsk National Medical University», Donetsk}

\section{PRESENCE AND LOCALIZATION OF MICROFLORA IN TEETH WITH DESTRUCTIVE FORMS OF PERIODONTITIS}

The species composition and pathogenic properties of tooth microflora with periodontal pathology have been studied for a long time, but little attention has been paid to the presence and localization of microflora in teeth with chronic periodontitis, including in the acute stage. Our goal was to study the presence and localization of microflora in teeth with destructive forms of periodon- titis. It was found that in chronic forms of periodontitis and in the acute stage, the localization of microflora is the same, but its presence and prevalence in the hard tissues of the tooth is different.

Key words: periodontitis, microflora, presence, localization.

\section{ЛИТЕРАТУРА}

1. Siqueira J.F. Jr, Rôças I.N. A variety of endodontics microbiota again. J Dent. Res. 2009; 88 : 969-981.

2. Jacinto R.C., Gomes B.P., Ferraz C.C., Zaia A.A., Filho F.J. Microbiological analysis of infected root canals from symptomatic and asymptomatic teeth with periapical periodontitis and the antimicrobial susceptibility of some isolated anaerobic bacteria. Oral Microbiol Immunol. 2003; 18 (5): 285-292.

3. Мозговая Л.А., Задорина И.И., Быкова Л.П., Годовалов А.П. Микрофлора корневых каналов зубов в динамике лечения хронических форм апикального периодонтита. Саратовский научно-медицинский журнал. 2013; 9 (3): 447-449.

4. Таиров В. В., Мелехов С.В., Асташева Т.Б. Микробиологическая оценка эффективности остетропных препаратов при лечении хронического апикального периодонтита. Стоматология. 2013; 1 : 30-34.

5. Баяхметова А. А., Смагулова Е.Н., Мангытаева Б. Б., Баскакова И.В. Характеристика анаэробной микрофлоры корневых каналов при хроническом периодонтите. Наука и мир. 2015; 3 (4 (20): 81-84.

6. Усманова И.Н., Аль-Кофиш М.А.М., Лебедева А.И., Хуснаризанова Р.Ф., Усманов И.Р. Влияние микрофлоры полости рта на состояние микроциркуляции тканей пародонта. Уральский медицинский журнал. 2017; 7: 31-35.

7. Глинкина В.В., Глинкин В.В. Современный взгляд на этиологию инфекционных периодонтитов. Південноукраїнський медичний науковий журнал. 2016; 14: 33-35.

8. Глинкин В.В., Василенко И.В., Кондратюк Р.Б. Морфологические изменения в пульпе и периодонте зубов с деструктивными формами апикального периодонтита в стадии обострения. Международный научный журнал «United-Journal». 2019; 30: 13-19.

9. Шабанов М. М. Клинико-морфологические особенности первичного и вторичного хронического верхушечного периодонтита : автореф. дис. ... канд. мед. наук. Тверь; 2004. 21.

10. Гречишников В. В. Эндодонто-периодонтальная патология: патоморфологическая характеристика, повышение эффективности диагностики и лечения: автореф. дис. ... доктора мед. наук. Санкт-Петербург; 2014. 33.

11. Глинкина В.В., Глинкин В.В. Морфологическое обоснование этиопатогенеза инфекционных периодонтитов. Південноукраїнський медичний науковий журнал. 2016; 15: 33-35.

12. Меркулов Г.А. Курс патологической техники. Л.; 1969. 423.

\section{REFERENCES}

1. Siqueira J.F. Jr, Rôças I.N. A variety of endodontics microbiota again. J Dent. Res. 2009; 88 : 969-981.

2. Jacinto R.C., Gomes B.P., Ferraz C.C., Zaia A.A., Filho F.J. Microbiological analysis of infected root canals from symptomatic and asymptomatic teeth with periapical periodontitis and the antimicrobial susceptibility of some isolated anaerobic bacteria. Oral Microbiol Immunol. 2003; $18(5): 285-292$.

3. Mozgovaya L.A., Zadorina I.I., Bykova L.P., Godovalov A.P. Mikroflora kornevyh kanalov zubov v dinamike lecheniya hronicheskih form apikal'nogo periodontita [Microflora of dental root canals in the dynamics of treatment of chronic forms of apical periodontitis]. Saratovskij nauchno-medicinskij zhurnal. 2013; 9 (3): 447-449 (in Russian).

4. Tairov V. V., Melekhov S.V., Astasheva T.B. Mikrobiologicheskaya ocenka effektivnosti ostetropnyh preparatov pri lechenii hronicheskogo apikal'nogo periodontita. Stomatologiya. 2013; $1:$ 30-34 (in Russian).

5. Bayahmetova A. A., Smagulova E.N., Mangytaeva B. B., Baskakova I.V. Harakteristika anaerobnoj mikroflory kornevyh kanalov pri hronicheskom periodontite. Nauka i mir. 2015; 3 (4 (20): 81-84 (in Russian).

6. Usmanova I.N., Al'-Kofish M.A.M., Lebedeva A.I., Husnarizanova R.F., Usmanov I.R. Vliyanie mikroflory polosti rta na sostoyanie mikrocirkulyacii tkanej parodonta. Ural'skij medicinskij zhurnal. 2017; 7: 31-35 (in Russian).

7. Glinkina V.V., Glinkin V.V. Sovremennyj vzglyad na etiologiyu infekcionnyh periodontitov. Pivdennoukraïns'kij medichnij naukovij zhurnal. 2016; 14: 33-35 (in Russian).

8. Glinkin V.V., Vasilenko I.V., Kondratyuk R.B. Morfologicheskie izmeneniya $\mathrm{v}$ pul'pe i periodonte zubov $\mathrm{s}$ destruktivnymi formami apikal'nogo periodontita $\mathrm{v}$ stadii obostreniya. Mezhdunarodnyj nauchnyj zhurnal «UnitedJournal». 2019; 30: 13-19 (in Russian).

9. Shabanov M. M. Kliniko-morfologicheskie osobennosti pervichnogo i vtorichnogo hronicheskogo verhushechnogo periodontita : avtoref. dis.... kand. med. nauk. Tver'; 2004. 21 (in Russian).

10. Grechishnikov V. V. Endodonto-periodontal'naya patologiya: patomorfologicheskaya harakteristika, povyshenie effektivnosti diagnostiki i lecheniya: avtoref. dis. ... doktora med. nauk. Sankt-Peterburg; 2014. 33 (in Russian).

11. Glinkina V.V., Glinkin V.V. Morfologicheskoe obosnovanie etiopatogeneza infekcionnyh periodontitov. Pivdennoukraïns'kij medichnij naukovij zhurnal. 2016; 15: 33-35 (in Russian).

12. Merkulov G.A. Kurs patologicheskoj tekhniki. L.; 1969. 423 (in Russian). 